\title{
Article \\ Fresh Basil Infusion: Effect of Sous-Vide Heat Treatment on Their Volatile Composition Profile, Sensory Profile, and Color
}

\author{
Artur Głuchowski ${ }^{1} \mathbb{D}$, Ewa Czarniecka-Skubina ${ }^{1, *(\mathbb{D})}$, Krzysztof Tambor ${ }^{1}$ and Elvyra Jariené $^{2}$ (D) \\ 1 Department of Food Gastronomy and Food Hygiene, Institute of Human Nutrition Sciences, \\ Warsaw University of Life Sciences (WULS), 02-778 Warsaw, Poland; artur_gluchowski@sggw.edu.pl (A.G.); \\ krzysztof_tambor@sggw.edu.pl (K.T.) \\ 2 Institute of Agricultural and Food Sciences, Agriculture Academy, Vytautas Mangus University, \\ LT-53361 Kaunas, Lithuania; elvyra.jariene@vdu.lt \\ * Correspondence: ewa_czarniecka_skubina@sggw.edu.pl; Tel.: +48-22-593-7063
}

check for

updates

Citation: Głuchowski, A.;

Czarniecka-Skubina, E.; Tambor, K.; Jariené, E. Fresh Basil Infusion: Effect of Sous-Vide Heat Treatment on Their Volatile Composition Profile, Sensory Profile, and Color. Molecules 2022, 27,

5. https://doi.org/10.3390/

molecules27010005

Academic Editors: Natalia Drabińska and Ben de Lacy Costello

Received: 30 November 2021

Accepted: 18 December 2021

Published: 21 December 2021

Publisher's Note: MDPI stays neutral with regard to jurisdictional claims in published maps and institutional affiliations.

Copyright: (C) 2021 by the authors. Licensee MDPI, Basel, Switzerland. This article is an open access article distributed under the terms and conditions of the Creative Commons Attribution (CC BY) license (https:// creativecommons.org/licenses/by/ $4.0 /)$.

\begin{abstract}
Herbs, including basil, are used to enhance the flavor of food products around the world. Its potential is influenced by the quality of fresh herbs and processing practices, wherein conditions of heat treatment play an important role. The aim of the research was to determine the effect of sous-vide heat treatment on the volatile compounds profile, sensory quality, and color of basil infusions. The material used for research was aqueous basil infusion prepared conventionally at $100{ }^{\circ} \mathrm{C}$, and using the sous-vide method $\left(65,75\right.$, and $\left.85^{\circ} \mathrm{C}\right)$. The composition of volatile compounds was identified by GC/MS analysis, the sensory profile was assessed using a group of trained panelists, while the color was instrumentally assessed in the CIE Lab system. No significant differences were found in the intensity of the taste and aroma of basil infusions at different temperatures. Seventy headspace volatile compounds were identified in the analyzed samples, ten of which exceeded $2 \%$ of relative area percentage. The most abundant compounds were eucalyptol (27.1\%), trans-ocimene (11.0\%), $\beta$-linalool (9.2\%), and $\beta$-myrcene (6.7\%). Most of the identified compounds belonged to the terpenes and alcohols groups. Our findings show that the conventional herbal infusion was more like a sous-vide infusion prepared at the lowest temperature $\mathrm{SV}_{65}$, while $\mathrm{SV}_{75}$ and $\mathrm{SV}_{85}$ were similar to each other but different from the conventional. However, a smaller number of volatile compounds in the samples heated at higher temperatures of sous-vide were identified. The sous-vide samples showed a higher content of alkanes. The sous-vide method ( $p \leq 0.05)$ resulted in darker, less green, and less yellow basil leaves than fresh and traditionally steeped ones. Long heat treatment under vacuum at higher temperatures causes a pronounced change in the aroma composition.
\end{abstract}

Keywords: sous-vide; basil; infusion; sensory quality; volatile compounds profile; color

\section{Introduction}

Herbs play an important role as natural flavoring substances during food processing. Application of the herb maceration and the infusion processes, and a medium that is a solvent (e.g., water, alcohol, and fat), enable herb wines, herbal tea infusions, aromatized vinegar, and oils commonly used for products like bread or vegetables to be made [1-6]. Recently, the popularity of herb macerates (e.g., for flavored oils in cooking or herb syrups in mixology) in the foodservice industry, as well as herbal infusions among consumers, has significantly increased [7]. They are used not only for seasoning or hedonic reasons but also as a source of harmless natural antioxidants [8]. Herbal infusions are usually prepared by steeping the dried aromatic parts of plants such as roots, leaves, flowers, fruits, and other elements in hot or boiling water. Nowadays, many species of aromatic and medicinal plants such as chamomile, lemon balm, basil, peppermint, lemon thyme, lemongrass, or lemon verbena are used to produce these infusions [7,9]. Herbal infusions are widely used in the treatment of diverse disease conditions [10].

Basil (Ocimum basilicum L.) is an aromatic herb belonging to the Lamiaceae family that plays both a significant culinary and an ornamental role. It is an essential ingredient of 
Mediterranean and other cuisines due to its unique and pleasant aroma. In addition to its culinary application, basil is utilized by the pharmaceutical and cosmetic industries for its chemical composition [11-13], which mainly includes polyphenolic acids and flavonoids that exhibit antioxidant, antiviral, antibacterial, and therapeutic properties [13,14].

Food is a complex matrix that consists of protein, lipid, carbohydrate, and phenolic compounds as well as aroma compounds that interact with these components [15]. The basil aroma is a result of certain volatile compounds. These are classified into two main chemical groups: terpenoids and phenylpropanoids, which are produced in highly specialized structures known as peltate glandular trichomes (PGTs), located on the aerial parts of the plant, mainly the leaves $[16,17]$. The release level of the volatile compounds and other flavor constituents into the infusions decides their sensory quality [18]. The sensory quality of an infusion is affected by the quality of the herb used (soil and weather conditions, harvesting, processing, and storage practices), and the preparation practices (quality of water, mutual proportion of herb and solvent, steeping period, and temperature) $[7,9]$.

Sous-vide is a method of cooking food in thermostable vacuumed pouches under strictly controlled temperature and time parameters, offering improved flavor, texture, and nutritional values along with extended shelf life in comparison with conventional cooking methods [19]. Only a few researchers [20-22] have studied the effect of the sous-vide method on the quality of herbs. Alcusón et al. [21] stated that Borage stalks processed with the sous-vide method were lighter and greener than conventionally cooked stalks and had increased phenolic content and antioxidant activity.

Although the use of herbs and spices in dishes is intended to add new sensory notes, the lion's share of studies evaluated the bactericidal effect and the possibility to extend the shelf life of their oils on food of animal origin. The antimicrobial effect of rosemary and thyme oils [20] and sage oil [23] on L. monocytogenes in sous-vide beef as well as oregano oil [22] in sous-vide salmon was determined. Some studies investigated the effect of the herbs' addition on the sensory and nutritional value of plant-origin products. The positive effect of rosemary oil on the sensory quality of sliced potatoes [24], as well as on vitamin $\mathrm{C}$ and polyphenols in potatoes [25], was stated. Only a few studies aimed to evaluate the effect of sous-vide on fresh herbal plants. Recently published works were dedicated to evaluating the sensory profile of meat products with basil extract [26], as well as an aromatic profile of pesto [12], or in essential oils from various basil species [27].

Despite this interest, no one, to the best of our knowledge, has evaluated the sensory and volatile profile of fresh basil on a neutral matrix and basil heat treated at various temperatures. Therefore, the aim of the study was to determine the effect of sous-vide heat treatment on the sensory profile, volatile compounds' composition, and color of basil infusions in relation to the traditional method. A research hypothesis was made that the volatile compounds' profile of basil aqueous infusions heated in hermetic pouches under strictly controlled parameters is richer than under traditional infusion methods.

\section{Results}

\subsection{Volatile Compounds' Profile of Basil Infusion Produced with Various Methods}

The identified headspace volatile compounds and their relative area percentage are presented in Table 1. Seventy various volatile compounds were identified in the analyzed samples, ten of which exceeded $2 \%$ of relative area percentage (Table 1). Most of the identified compounds belonged to the terpenes and alcohols groups.

The highest number of volatile substances was identified in the samples of fresh herbs (97.7\% of the area), and slightly less in the $\mathrm{SV}_{65}$ and $\mathrm{T}_{100}$ samples $(93.5 \%$ and $93.8 \%$, respectively). A smaller share was identified in the samples heated at higher temperatures; $\mathrm{SV}_{75}$ and $\mathrm{SV}_{85}(82.6-83.0 \%)$, which results from the significant number of high-molecular compounds from the package accumulated in the headspace. The most abundant compounds in basil infusions and fresh basil samples were eucalyptol $(27.1 \%$-the average of all samples), trans-ocimene (11.0\%), $\beta$-linalool (9.2\%), and $\beta$-myrcene $(6.7 \%)$. 
Table 1. Effect of various heat treatment methods on the volatile profile of basil infusions.

\begin{tabular}{|c|c|c|c|c|c|c|c|c|}
\hline \multirow{3}{*}{$\begin{array}{l}\text { Volatile } \\
\text { Compound }\end{array}$} & \multirow{3}{*}{$\begin{array}{l}\text { Odor } \\
\text { Evocations } \\
\text { acc. to [28] }\end{array}$} & \multirow{3}{*}{ LRI } & \multirow{3}{*}{ LRI d.b. } & \multirow{2}{*}{ Fresh } & \multicolumn{3}{|c|}{ Sous-Vide Method } & \multirow{2}{*}{$\begin{array}{c}\text { Traditional } \\
\mathrm{T}_{100}\end{array}$} \\
\hline & & & & & $\mathrm{SV}_{65}$ & $\mathrm{SV}_{75}$ & $\mathrm{SV}_{85}$ & \\
\hline & & & & \multicolumn{5}{|c|}{ Relative Percentage Content (\%) $\bar{x} \pm S E$} \\
\hline Dimethyl sulfide & $\begin{array}{l}\text { cabbage, sulfur, } \\
\text { gasoline }\end{array}$ & N/D & 521 & $0.42 \pm 0.15^{\mathrm{a}}$ & $0.46 \pm 0.13^{\mathrm{a}}$ & $0.32 \pm 0.01^{\mathrm{a}}$ & $0.32 \pm 0.01^{\mathrm{a}}$ & $0.12 \pm 0.01^{\mathrm{a}}$ \\
\hline Hexane & - & 801 & 800 & $0.12 \pm 0.10^{\mathrm{a}}$ & - & - & - & $0.0^{\mathrm{a}} \pm 0.10^{\mathrm{a}}$ \\
\hline 3-hexenal & leafy, green & 803 & 803 & $0.16 \pm 0.01$ & - & - & - & - \\
\hline (E)-2-Hexenal & - & 852 & 854 & $0.27 \pm 0.12^{\mathrm{a}}$ & - & - & - & $0.22 \pm 0.10^{\mathrm{a}}$ \\
\hline 3-Hexen-1-ol & freshly cut grass & 855 & 853 & $6.20 \pm 0.48^{b}$ & - & $0.05 \pm 0.01^{\mathrm{a}}$ & - & $0.18 \pm 0.04^{\mathrm{a}}$ \\
\hline (E)-2-hexen-1-ol & green fruity & 866 & 867 & $0.71 \pm 0.17$ & - & - & - & - \\
\hline 1-Hexanol & flower, green & 869 & 867 & $0.94 \pm 0.23$ & - & - & - & - \\
\hline Tricyclene & - & 920 & 924 & $0.01 \pm 0.00^{\mathrm{a}}$ & - & $0.02 \pm 0.00^{b}$ & - & - \\
\hline$\alpha$-Thujene & $\begin{array}{l}\text { wood, green, } \\
\text { herb }\end{array}$ & 927 & 927 & $0.25 \pm 0.04^{a}$ & $0.32 \pm 0.04^{\mathrm{b}}$ & $0.66 \pm 0.02^{b}$ & $0.48 \pm 0.01^{b}$ & $0.29 \pm 0.05^{\mathrm{a}}$ \\
\hline$\alpha$-Pinene & pine, turpentine & 932 & 934 & $1.69 \pm 0.13^{\mathrm{a}}$ & $2.10 \pm 0.49^{\mathrm{a}}$ & $3.16 \pm 0.09^{b}$ & $2.95 \pm 0.01^{b}$ & $2.33 \pm 0.15^{\mathrm{a}}$ \\
\hline Camphene & camphor & 947 & 948 & $0.55 \pm 0.07^{\mathrm{a}}$ & $0.62 \pm 0.10^{a}$ & $1.04 \pm 0.03^{b}$ & $1.07 \pm 0.10^{b}$ & $0.84 \pm 0.06^{\mathrm{a}, \mathrm{b}}$ \\
\hline Sabinene & $\begin{array}{c}\text { pepper, } \\
\text { turpentine, wood }\end{array}$ & 972 & 972 & $2.38 \pm 0.17^{\mathrm{a}}$ & $2.65 \pm 0.16^{a}$ & $3.11 \pm 0.09^{a}$ & $2.97 \pm 0.60^{a}$ & $3.97 \pm 0.39^{a}$ \\
\hline$\beta$-pinene & $\begin{array}{l}\text { pine, resin, } \\
\text { turpentine }\end{array}$ & 975 & 974 & $3.66 \pm 0.23^{a}$ & $3.46 \pm 0.54^{\mathrm{a}}$ & $5.25 \pm 0.15^{b}$ & $5.23 \pm 0.18^{b}$ & $5.17 \pm 0.37^{b}$ \\
\hline 1-Octen-3-ol & mushroom & 981 & 980 & $0.42 \pm 0.08^{a}$ & $0.94 \pm 0.14^{b}$ & $0.21 \pm 0.01^{\mathrm{a}}$ & - & - \\
\hline 3-Octanone & nut & 988 & 988 & $0.20 \pm 0.06^{b}$ & $0.07 \pm 0.01^{a}$ & $0.04 \pm 0.00^{\mathrm{a}}$ & - & $0.05 \pm 0.03^{a}$ \\
\hline$\beta$-Mircene & balsamic, spicy & 991 & 992 & $4.10 \pm 0.17^{\mathrm{a}}$ & $4.78 \pm 0.27^{\mathrm{a}}$ & $8.59 \pm 0.25^{b}$ & $5.74 \pm 0.32^{\mathrm{a}}$ & $10.03 \pm 0.9^{b}$ \\
\hline Decane & alkane & 1000 & 1000 & - & $0.17 \pm 0.03^{a}$ & $0.09 \pm 0.02^{\mathrm{a}}$ & $0.12 \pm 0.03^{a}$ & $\begin{array}{c}-10.00+0 \\
-\end{array}$ \\
\hline$\alpha$-Phellandrene & turpentine, mint & 1003 & 1003 & $0.35 \pm 0.06^{\mathrm{a}}$ & - & - & - & $1.16 \pm 0.08^{b}$ \\
\hline Octanal & fat, soap, lemon & 1004 & 1007 & - & $1.11 \pm 0.10^{\mathrm{a}}$ & $1.23 \pm 0.04^{\mathrm{a}}$ & $1.18 \pm 0.032^{\mathrm{a}}$ & - \\
\hline$\delta 3$-carene & lemon, resin & 1008 & 1008 & $1.44 \pm 0.19^{c}$ & $0.47 \pm 0.04^{\mathrm{a}}$ & $0.66 \pm 0.02^{a}$ & $0.85 \pm 0.19^{a, b}$ & $1.02 \pm 0.09^{b}$ \\
\hline$\alpha$-Terpinene & lemon & 1016 & 1015 & $0.22 \pm 0.04^{a}$ & $0.31 \pm 0.02^{b, c}$ & $0.42 \pm 0.01^{c}$ & $0.53 \pm 0.04^{c}$ & $0.32 \pm 0.05^{a, b}$ \\
\hline $\begin{array}{l}\text { 2-Hexen-1-ol, } \\
\text { acetate }\end{array}$ & - & 1119 & 1119 & $0.04 \pm 0.01$ & - & - & - & - \\
\hline o-Cymene & $\begin{array}{l}\text { lavender and } \\
\text { cypress }\end{array}$ & 1021 & 1021 & $0.01 \pm 0.01$ & - & - & - & - \\
\hline p-Cymene & gasoline, citrus & 1024 & 1023 & $0.16 \pm 0.03^{a}$ & $0.12 \pm 0.00^{\mathrm{a}}$ & $0.19 \pm 0.01^{\mathrm{a}}$ & $0.20 \pm 0.04^{\mathrm{a}}$ & $0.16 \pm 0.03^{a}$ \\
\hline Limonene & sweet, citrus & 1028 & 1028 & $3.05 \pm 0.26^{b}$ & $2.01 \pm 0.02^{\mathrm{a}}$ & $2.74 \pm 0.08^{a}$ & $1.97 \pm 0.49^{\mathrm{a}}$ & $5.09 \pm 0.26^{b}$ \\
\hline Eucalyptol & eucalyptus, herb & 1030 & 1030 & $24.91 \pm 1.23^{b}$ & $39.44 \pm 1.03^{c}$ & $26.53 \pm 0.77^{b}$ & $30.30 \pm 4.19^{b}$ & $14.21 \pm 3.08^{a}$ \\
\hline cis-Ocimene & $\begin{array}{c}\text { citrus, green, } \\
\text { wood, terpene }\end{array}$ & 1039 & 1040 & $0.31 \pm 0.01^{\mathrm{a}}$ & $0.24 \pm 0.02^{\mathrm{a}}$ & $0.47 \pm 0.01^{\mathrm{b}}$ & $0.41 \pm 0.02^{\mathrm{b}}$ & $0.60 \pm 0.04^{c}$ \\
\hline trans-Ocimene & herb & 1049 & 1050 & $11.17 \pm 0.46^{b}$ & $7.65 \pm 0.42^{\mathrm{a}}$ & $10.61 \pm 0.31^{\mathrm{b}}$ & $9.03 \pm 0.53^{\mathrm{a}}$ & $16.66 \pm 1.03^{c}$ \\
\hline$\gamma$-Terpinene & $\begin{array}{l}\text { gasoline, } \\
\text { turpentine }\end{array}$ & 1058 & 1058 & $0.27 \pm 0.04^{\mathrm{a}}$ & $0.42 \pm 0.02^{b}$ & $0.64 \pm 0.02^{c}$ & $0.67 \pm 0.06^{c}$ & $0.46 \pm 0.06^{b}$ \\
\hline $\begin{array}{l}\text { Sabinene hydrate } \\
\text { trans }\end{array}$ & wood, balsamic & 1067 & 1067 & $0.20 \pm 0.01^{\mathrm{b}}$ & $0.20 \pm 0.02^{b}$ & $0.06 \pm 0.01^{\mathrm{a}}$ & - & $0.17 \pm 0.03^{b}$ \\
\hline 1-Octanol & $\begin{array}{l}\text { forest, lemon, } \\
\text { fatty }\end{array}$ & 1080 & 1078 & $0.07 \pm 0.01^{\mathrm{b}}$ & $0.04 \pm 0.00^{\mathrm{a}}$ & $0.03 \pm 0.00^{\mathrm{a}}$ & - & 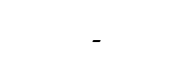 \\
\hline Terpinolene & pine, lemon, lime & 1088 & 1088 & $3.57^{\mathrm{b}} \pm 0.58^{\mathrm{b}}$ & $1.63 \pm 0.16^{\mathrm{a}}$ & $2.12 \pm 0.06^{\mathrm{a}}$ & $2.26 \pm 0.31^{\mathrm{a}}$ & $4.43 \pm 0.33^{b}$ \\
\hline Undecene & alkane & 1092 & 1092 & - & $0.02 \pm 0.02^{\mathrm{a}}$ & - & - & $0.13 \pm 0.13^{a}$ \\
\hline$\beta$-Linalool & flower, lavender & 1100 & 1100 & $4.96 \pm 1.34^{\mathrm{a}}$ & $13.89^{\mathrm{c}} \pm 1.8$ & $8.01 \pm 0.23^{b}$ & $9.51 \pm 1.0^{\mathrm{b}}$ & $9.40^{\mathrm{b}} \pm 0.41$ \\
\hline Nonanal & fat, citrus, green & 1107 & 1104 & - & $0.16 \pm 0.02^{a}$ & - & - & $0.16 \pm 0.01^{\mathrm{a}}$ \\
\hline $\begin{array}{l}\text { p-Mentha-1,3,8- } \\
\text { triene }\end{array}$ & turpentine & 1111 & 1113 & $0.02 \pm 0.01^{\mathrm{a}}$ & - & $0.02 \pm 0.00^{\mathrm{a}}$ & - & $0.02 \pm 0.01^{\mathrm{a}}$ \\
\hline Methyl caprylate & fruity, green & 1125 & 1125 & - & - & $0.04 \pm 0.00^{\mathrm{a}}$ & $0.03 \pm 0.03^{a}$ & $0.06 \pm 0.00^{\mathrm{a}}$ \\
\hline Allo-Ocimene & & 1128 & 1130 & - & - & $0.31 \pm 0.01$ & - & - \\
\hline Cosmene & bay leafy & 1129 & 1134 & $0.12 \pm 0.01^{\mathrm{a}}$ & $0.10 \pm 0.01^{\mathrm{a}}$ & - & $0.14 \pm 0.08^{\mathrm{a}}$ & $0.15 \pm 0.01^{\mathrm{a}}$ \\
\hline Camphor & camphor & 1143 & 1143 & $2.40 \pm 0.27^{b}$ & $2.51 \pm 0.33^{b}$ & $1.90 \pm 0.05^{b}$ & $1.84 \pm 0.016^{b}$ & $1.27 \pm 0.16^{\mathrm{a}}$ \\
\hline Borneol & camphor & 1165 & 1165 & $0.20 \pm 0.04^{a}$ & $0.34 \pm 0.06^{a}$ & $0.17 \pm 0.02^{\mathrm{a}}$ & $0.21 \pm 0.02^{\mathrm{a}}$ & $0.20 \pm 0.03^{a}$ \\
\hline Terpinen-4-ol & $\begin{array}{l}\text { pine, pepper, } \\
\text { wood }\end{array}$ & 1178 & 1178 & - & $0.07 \pm 0.01^{\mathrm{a}}$ & $0.06 \pm 0.02^{\mathrm{a}}$ & $0.11 \pm 0.01^{b}$ & $0.04 \pm 0.01^{\mathrm{a}}$ \\
\hline$\alpha$-Terpineol & floral, lilac & 1191 & 1187 & - & $0.33 \pm 0.04^{\mathrm{b}}$ & $0.15 \pm 0.01^{\mathrm{a}}$ & $0.15 \pm 0.08^{a}$ & $0.25 \pm 0.03^{a, b}$ \\
\hline Estragole & licorice, anise & 1198 & 1199 & $0.22 \pm 0.05^{b}$ & - & $0.13 \pm 0.01^{\mathrm{a}}$ & - & $0.27 \pm 0.03^{b}$ \\
\hline Dodecane & alkane & 1200 & 1200 & - & $0.95 \pm 0.16^{\mathrm{b}}$ & $0.45 \pm 0.01^{\mathrm{a}}$ & $0.62 \pm 0.03^{a}$ & - \\
\hline Bornyl acetate & $\begin{array}{l}\text { camphor, sweet, } \\
\text { pine, herb }\end{array}$ & 1287 & 1285 & $0.06 \pm 0.01^{\mathrm{a}}$ & $1.00 \pm 0.08^{c}$ & $0.73 \pm 0.02^{b}$ & $0.79 \pm 02^{b}$ & $2.10 \pm 0.09^{\mathrm{d}}$ \\
\hline Tridecane & alkane & 1300 & 1300 & - & $0.42 \pm 0.08^{b}$ & $0.24 \pm 0.01^{\mathrm{a}}$ & $0.28 \pm 0.00^{\mathrm{a}}$ & - \\
\hline$\alpha$-Cubebene & herb, wax & 1351 & 1351 & $0.24 \pm 0.12^{\mathrm{a}}$ & $0.07 \pm 0.01^{\mathrm{a}}$ & $0.05 \pm 0.00^{\mathrm{a}}$ & $0.02 \pm 0.01^{\mathrm{a}}$ & $0.21 \pm 0.04^{\mathrm{a}}$ \\
\hline Eugenol & clove, honey & 1359 & 1360 & $0.51 \pm 0.28^{a}$ & $1.86 \pm 0.32^{b}$ & $0.80 \pm 0.02^{a}$ & $1.47 \pm 0.20^{b}$ & $1.39 \pm 0.10^{b}$ \\
\hline
\end{tabular}


Table 1. Cont.

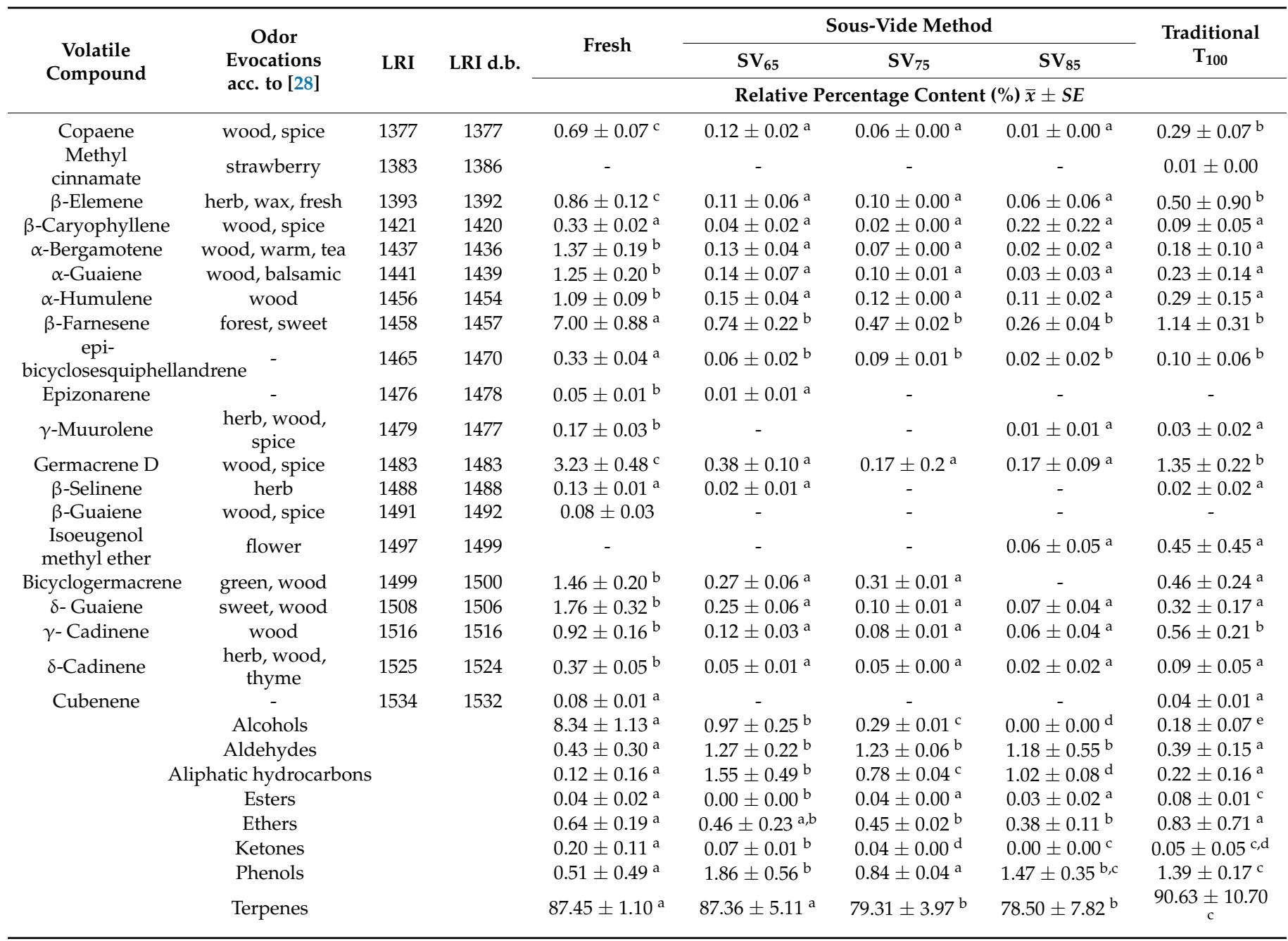

LRI-linear retention index calculated experimentally; LRI d.b.--linear retention index from the NIST database. N/D—no data; SE—-standard error; ${ }^{a}$, b, c, d_mean values marked by different letters in verses, differ significantly at $p \geq 0.05 . \mathrm{SV}_{65}, \mathrm{SV}_{75}, \mathrm{SV}_{85}$-temperature of sous-vide method.

The profile of volatile compounds in the analyzed infusions differed significantly depending on the parameters applied (Table 1). Sous-vide infusions, unlike fresh basil samples, did not contain compounds responsible for the notes of freshly cut grass or leaves. The most notable were 3-hexene-1-ol, 1-hexanol, and 2-hexene-1-ol. However, they were detected in small amounts in traditional infusions. The exception was 3-hexene-1-ol, trace amounts of which $(0.05 \%)$ were found in the $\mathrm{SV}_{75}$ sample. Moreover, fewer volatile compounds were identified in sous-vide aqueous infusions than in traditional infusions. Sous-vide samples treated at higher temperatures $\left(\mathrm{SV}_{75}\right.$ and $\left.\mathrm{SV}_{85}\right)$ had a higher proportion of $\alpha$-thujene, $\alpha$-pinene, camphene, $\beta$-pinene, and $\alpha$-terpinene (having piney and woody evocations) than the $\mathrm{SV}_{65}$ or traditional infusion samples. Basil infusions had a greater share of $\gamma$-terpinene, $\beta$-linalool, bornyl acetate, and eugenol (mainly sweet, floral, and spicy notes) than fresh basil. On the other hand, heat treatment negatively influenced the share of volatile compounds responsible for forest and wood notes in the profile. The most noticeable was the decrease in the content of $\beta$-farnesene and germacrene $\mathrm{D}$.

Traditional infusions, in contrast to those prepared using the sous-vide method, did not significantly reduce the share of compounds such as limonene, terpinolene with citrus notes, and estragole with licorice and anise notes. The content of copaene and $\beta$-element in the traditional infusion, although different from the content in the fresh basil, was statistically significantly higher than in the sous-vide infusions. The high initial temperature of the 
water and atmospheric conditions in the traditional infusion resulted in a significantly lower share of volatile compounds like eucalyptus and camphor. However, a greater share of $\beta$-myrcene, $\alpha$-phellandrene, and trans-ocimene was found in them. In the sousvide samples, in contrast to the others, alkanes (decane, dodecane, and tridecane) and octane, responsible for green, lemon, and soap notes, were identified. With the increasing temperature, an increase in the share of $\delta 3$-caren and cis-ocimene was also determined.

\subsection{Sensory Profile of Sous-Vide Basil Infusions}

There was no significant effect of temperature on the odor and flavor profile assessed by panelists (Table 2 ). However, non-significant $(p>0.05)$ observation of a slight decrease in fresh and natural basil odor and flavor intensities were noted as the process temperature increase.

Table 2. Effect of various heat treatment methods on the sensory profile of basil infusions.

\begin{tabular}{|c|c|c|c|c|}
\hline \multirow{3}{*}{ Attribute } & \multicolumn{3}{|c|}{ Sous-Vide Method } & \multirow{2}{*}{$\begin{array}{c}\text { Traditional } \\
\mathrm{T}_{100}\end{array}$} \\
\hline & $\mathrm{SV}_{65}$ & $\mathrm{SV}_{75}$ & $\mathrm{SV}_{85}$ & \\
\hline & \multicolumn{4}{|c|}{ Intensity (0-10 c.u.) $\bar{x} \pm \mathrm{SE}$} \\
\hline Fresh odor & $4.4 \pm 0.5^{\mathrm{a}}$ & $4.5 \pm 0.5^{\mathrm{a}}$ & $3.7 \pm 0.5^{\mathrm{a}}$ & $4.3 \pm 0.5^{\mathrm{a}}$ \\
\hline Natural basil odor & $5.1^{\mathrm{a}} \pm 0.5^{\mathrm{a}}$ & $5.2 \pm 0.5^{\mathrm{a}}$ & $4.8 \pm 0.5^{\mathrm{a}}$ & $4.8 \pm 0.5^{\mathrm{a}}$ \\
\hline Herbal odor & $3.8^{\mathrm{a}} \pm 0.5^{\mathrm{a}}$ & $3.7 \pm 0.5^{\mathrm{a}}$ & $3.2 \pm 0.4^{\mathrm{a}}$ & $3.3 \pm 0.5^{\mathrm{a}}$ \\
\hline Sweet odor & $4.0^{\mathrm{a}} \pm 0.6^{\mathrm{a}}$ & $3.2 \pm 0.5^{\mathrm{a}}$ & $3.0 \pm 0.5^{\mathrm{a}}$ & $3.5 \pm 0.4^{\mathrm{a}}$ \\
\hline Pungent odor & $1.7^{\mathrm{a}} \pm 0.4^{\mathrm{a}}$ & $1.9 \pm 0.4^{\mathrm{a}}$ & $2.0 \pm 0.5^{\mathrm{a}}$ & $1,6 \pm 0.5^{\mathrm{a}}$ \\
\hline Clove odor & $2.3^{\mathrm{a}} \pm 0.4^{\mathrm{a}}$ & $2.3 \pm 0.3^{a}$ & $1.6 \pm 0.2^{\mathrm{a}}$ & $2.2 \pm 0.3^{\mathrm{a}}$ \\
\hline Anise odor & $2.0^{\mathrm{a}} \pm 0.4^{\mathrm{a}}$ & $1.8 \pm 0.4^{\mathrm{a}}$ & $1.4 \pm 0.3^{\mathrm{a}}$ & $1.6 \pm 0.3^{\mathrm{a}}$ \\
\hline Color intensity & $7.0 \pm 0.5^{\mathrm{d}}$ & $6.0 \pm 0.4^{c}$ & $1.2 \pm 0.2^{\mathrm{a}}$ & $4.1 \pm 0.4^{b}$ \\
\hline Natural basil flavor & $5.4 \pm 0.4^{\mathrm{a}}$ & $5.0 \pm 0.5^{\mathrm{a}}$ & $4.9 \pm 0.6^{\mathrm{a}}$ & $4.4 \pm 0.6^{\mathrm{a}}$ \\
\hline Fresh flavor & $4.1 \pm 0.8^{a}$ & $2.9 \pm 0.8^{a}$ & $3.1 \pm 0.7^{\mathrm{a}}$ & $3.9 \pm 0.6^{\mathrm{a}}$ \\
\hline Herbal flavor & $3.8 \pm 0.6^{\mathrm{a}}$ & $3.7 \pm 0.4^{\mathrm{a}}$ & $3.5 \pm 0.5^{\mathrm{a}}$ & $3.9 \pm 0.5^{\mathrm{a}}$ \\
\hline Sweet taste & $2.2 \pm 0.4^{\mathrm{a}}$ & $1.6 \pm 0.3^{\mathrm{a}}$ & $1.8 \pm 0.3^{\mathrm{a}}$ & $2.1 \pm 0.4^{\mathrm{a}}$ \\
\hline Bitter taste & $1.3 \pm 0.3^{\mathrm{a}}$ & $1.7 \pm 0.3^{\mathrm{a}}$ & $2.0 \pm 0.4^{\mathrm{a}}$ & $2.0 \pm 0.4^{\mathrm{a}}$ \\
\hline Astringent sensation & $2.0 \pm 0.4^{\mathrm{a}}$ & $2.3 \pm 0.4^{\mathrm{a}}$ & $2.4 \pm 0.4^{\mathrm{a}}$ & $2.5 \pm 0.5^{\mathrm{a}}$ \\
\hline Aftertaste & $3.8 \pm 0.6^{\mathrm{a}}$ & $3.7 \pm 0.5^{\mathrm{a}}$ & $3.6 \pm 0.6^{\mathrm{a}}$ & $3.5 \pm 0.5^{\mathrm{a}}$ \\
\hline
\end{tabular}

c.u.-conventional unit; SE-standard error; ${ }^{a}, b, c, d$ - different lowercase letters in rows indicate significant differences in color depending on the parameters applied at $p \leq 0.05$.

The color of basil infusions was also affected by temperature $(p<0.05)$. As the temperature of sous-vide increased, color intensity decreased. The color of traditional infusions was more intense than sous-vide infusions processed at $85^{\circ} \mathrm{C}$.

The individual sensory characteristics of basil infusions are highly correlated with the selected volatile compounds as follows:

- Natural basil odor and herbal odor-1-octanol, respectively, $r=0.97$ and $r=0.99$;

- $\quad$ Sweet odor $-\beta$-Linalool (0.98), Borneol (0.97), $\alpha$-Terpineol (0.96);

- $\quad$ Pungent odor- $\alpha$-Terpinene (0.96), $\gamma$-Terpinene (0.99);

- Natural basil flavor-Dimethyl sulfide (0.99), Eucalyptol (0.97), Dodecane (0.96),

Tridecane (0.98);

- $\quad$ Fresh flavor-Nonanal (0.98), $\alpha$-Terpineol (0.95), $\beta$-Selinene (0.99);

- Herbal flavor-3-Octanone (0.99), Sabinene hydrate trans (0.96);

- $\quad$ Sweet taste- $\alpha$-Terpineol (0.97);

- $\quad$ Bitter taste-3-Octanone (0.96);

- $\quad$ Astringent sensation-aftertaste-Dimethyl sulfide (0.98), Tridecane (0.96).

The results of Principal Component Analysis (PCA) of the sensory and volatile profiles of basil infusions are presented in Figure 1. The first two principal components of PCA explained $92.4 \%$ of the total variability between the samples of basil infusions, but $81.05 \%$ of the variance was attributed to PC1, which was strongly associated with color intensity. 


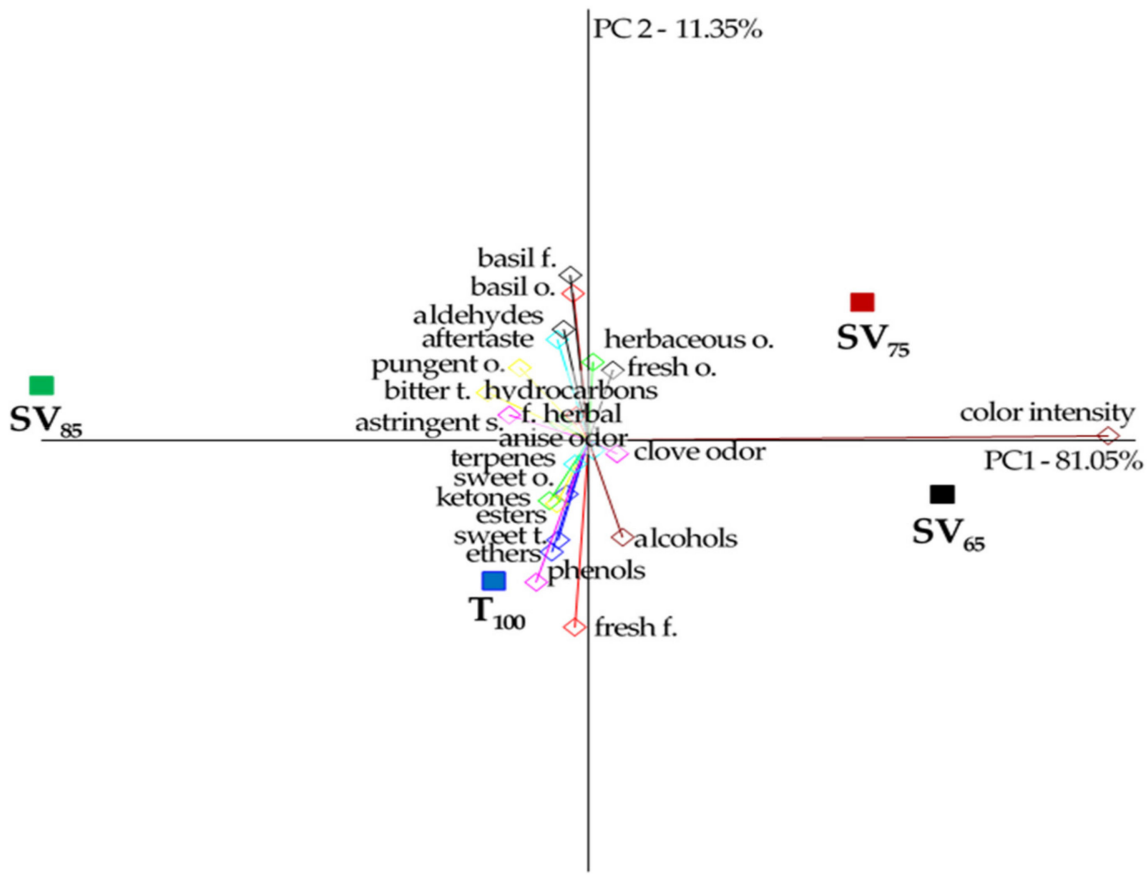

Figure 1. Principal components analysis (PCA) biplot of basil infusions $\left(\mathrm{SV}_{65}, \mathrm{SV}_{75}, \mathrm{SV}_{85}\right.$, and $\left.\mathrm{T}_{100}\right)$.

The second principal component demonstrates a relationship between flavor and odor intensity and the content of volatile compounds groups. The intensity of natural basil odor and flavor as well as aftertaste intensity was related to the aldehydes content and was negatively related to traditional basil infusions $\left(\mathrm{T}_{100}\right)$, which is proven by the location of those attributes on the opposite side of the plot origin. Fresh flavor and sweetness were related the most with phenols and ethers content. These vectors were closely related to sample $\mathrm{T}_{100}$.

Generally, in terms of the volatile composition as well as flavor and odor intensities, a traditionally infused sample was more like a sous-vide infusion cooked at the lowest temperature; $\mathrm{SV}_{65}$, while $\mathrm{SV}_{75}$ was more similar to $S V_{85}$, as shown by the contrary location of these samples relative to the $\mathrm{OX} X$-axis. It can be concluded that prolonged heat treatment in a vacuum at higher temperatures causes a pronounced change in aroma composition.

\subsection{The Color of Infusions and Basil Leaves Measured Instrumentally}

The instrumental color measurement of basil infusions performed immediately after their preparation revealed that along with the increasing temperature of the sous-vide method, the color of infusions became brighter $\left(\mathrm{L}^{*}\right)$, and less red $\left(\mathrm{a}^{*}\right)$ and yellow $\left(\mathrm{b}^{*}\right)$. The color of traditional infusions was like $\mathrm{SV}_{75}\left(\mathrm{~L}^{*}, \mathrm{a}^{*}\right)$ but significantly less yellow. Only the color of $\mathrm{SV}_{85}$ samples, did not change significantly after $2 \mathrm{~h}$ of storage under atmospheric conditions. In other cases, the color became darker, redder, and usually yellower (Table 3).

The color of basil leaves was affected by the heat treatment $(p \leq 0.05)$ and became darker, less green, and less yellow. With the temperature increase in the sous-vide treated samples, there was a proportional decrease in greenness, but not in lightness and yellowness. The color of conventionally steeped basil leaves was the least changed. Conventional samples were significantly darker but did not differ in yellowness and greenness from fresh leaves. The total color difference $(\Delta \mathrm{E})$ of sous-vide treated leaves (38.6-42.9) increased with the temperature and was higher than the traditionally infused (20.4). This is caused by a lower color chroma (C) of sous-vide samples (17.5-13.9) when compared to $\mathrm{T}_{100}$ samples (34.0). The most changed color from conventionally heated leaves had sample processed at the highest temperature of sous-vide $\mathrm{SV}_{85}$ (Table 3). 
Table 3. The color of basil leaves and infusions measured instrumentally.

\begin{tabular}{|c|c|c|c|c|c|c|}
\hline \multirow{2}{*}{ Color } & \multirow{2}{*}{\multicolumn{2}{|c|}{ Fresh }} & \multicolumn{3}{|c|}{ Sous Vide Method $\bar{x} \pm S E$} & \multirow{2}{*}{$\begin{array}{c}\text { Traditional } \\
\mathbf{T}_{100}\end{array}$} \\
\hline & & & $\mathrm{SV}_{65}$ & $\mathrm{SV}_{75}$ & $\mathrm{SV}_{85}$ & \\
\hline \multirow{3}{*}{$\begin{array}{l}\text { Color of infusion } \\
\text { after preparation }\end{array}$} & $\mathrm{L}$ & - & $26.79 \pm 0.83^{\mathrm{a}, \mathrm{A}}$ & $30.25 \pm 1.20^{\mathrm{b}, \mathrm{A}}$ & $36.77 \pm 0.94^{\mathrm{c}, \mathrm{A}}$ & $32.82 \pm 0.77^{\mathrm{b}, \mathrm{A}}$ \\
\hline & $\mathrm{a}$ & - & $8.24 \pm 0.74^{\mathrm{c}, \mathrm{A}}$ & $4.48 \pm 0.75^{\mathrm{b}, \mathrm{A}}$ & $0.01 \pm 0.31^{\mathrm{a}, \mathrm{A}}$ & $5.46 \pm 0.44^{\mathrm{b}, \mathrm{A}}$ \\
\hline & $\mathrm{b}$ & - & $26.97 \pm 0.88^{c, A}$ & $21.91 \pm 1.05^{\mathrm{b}, \mathrm{A}}$ & $15.49 \pm 0.52^{\mathrm{a}, \mathrm{A}}$ & $17.43 \pm 0.48^{\mathrm{a}, \mathrm{A}}$ \\
\hline \multirow{3}{*}{$\begin{array}{l}\text { Color of infusion } \\
\text { after } 2 \mathrm{~h}\end{array}$} & $\mathrm{~L}$ & - & $16.51 \pm 0.46^{\mathrm{a}, \mathrm{B}}$ & $16.97 \pm 0.26^{\mathrm{a}, \mathrm{B}}$ & $36.24 \pm 0.46^{\mathrm{c}, \mathrm{A}}$ & $25.60 \pm 0.62^{b, B}$ \\
\hline & a & - & $17.11 \pm 0.31^{\mathrm{c}, \mathrm{B}}$ & $16.59 \pm 0.18^{\mathrm{c}, \mathrm{B}}$ & $0.22 \pm 0.31^{\mathrm{a}, \mathrm{A}}$ & $10.08 \pm 0.17^{\mathrm{b}, \mathrm{B}}$ \\
\hline & $\mathrm{b}$ & - & $23.24 \pm 0.46^{\mathrm{b}, \mathrm{B}}$ & $24.02 \pm 0.53^{\mathrm{b}, \mathrm{A}}$ & $15.30 \pm 0.46^{\mathrm{a}, \mathrm{A}}$ & $24.08 \pm 0.23^{\mathrm{b}, \mathrm{B}}$ \\
\hline \multirow{6}{*}{ Color of leaves } & $\mathrm{L}$ & $34.89^{c} \pm 0.83$ & $9.8 \pm 1.00^{\mathrm{a}}$ & $9.6 \pm 1.41^{\mathrm{a}}$ & $8.4^{\mathrm{a}} \pm 0.69^{\mathrm{a}}$ & $18.8 \pm 0.88^{b}$ \\
\hline & a & $-13.95^{\mathrm{d}} \pm 1.57$ & $-5.6 \pm 1.01^{\mathrm{a}}$ & $-3.8 \pm 0.51^{b}$ & $-0.3 \pm 0.32^{\mathrm{c}}$ & $-11.7 \pm 0.75^{d}$ \\
\hline & $\mathrm{b}$ & $45.14^{c} \pm 1.62$ & $16.6 \pm 1.70^{\mathrm{a}}$ & $15.4 \pm 2.77^{\mathrm{a}}$ & $14.2^{\mathrm{a}} \pm 1.18^{\mathrm{a}}$ & $31.6 \pm 1.49^{b}$ \\
\hline & $\mathrm{C}$ & 46.99 & 17.48 & 15.90 & 13.87 & 34.03 \\
\hline & $\Delta \mathrm{C}$ & - & 29.54 & 31.11 & 33.80 & 13.20 \\
\hline & $\Delta \mathrm{E}$ & - & 38.56 & 39.92 & 42.88 & 20.42 \\
\hline
\end{tabular}

SE—-standard error; $\mathrm{a}, \mathrm{b}, \mathrm{c}, \mathrm{d}$ — different lowercase letters in rows indicate significant differences in color depending on the parameters applied at $p \leq 0.05 ; \mathrm{A}, \mathrm{B}$-different uppercase letters in the column denote significant differences in infusion color after $2 \mathrm{~h}$ storage.

\section{Discussion}

\subsection{Effect of Various Heat Treatment Methods on the Aroma Profile of Basil Infusions}

Basil does not have one "right" aroma, and its aroma profile is heterogeneous [17]. Fresh basil aroma is a complex mixture of many volatile organic compounds (VOc) that are present in various proportions and have various odor activity values. Aroma quality depends on essential oil content and composition (mainly terpenoids and phenylpropanoids). The most abundant compounds in the aromatic profile of basil differed between authors: (Z)-3-hexenal, eucalyptol, linalool, and eugenol were indicated by Blank [29]; linalool, eucalyptol, and trans-bergamotene were pointed out by Ciriello et al. [12]; eucalyptol, linalool, and eugenol were reported by Ciriello et al. [11]; while linalool, eugenol, and cis-alpha-bergamotene, by Tirillini and Maggi [30]. In this study, the similar VOc of fresh basil (eucalyptol, linalool trans-ocimene, $\beta$-linalool, and $\beta$-myrcene) were dominant. These discrepancies in the most plentiful volatiles are normal, as four major essential oil chemotypes in O. basilicum were identified: estragole-rich; linalool-rich; methyl eugenol-rich; and methyl cinnamate rich [31]. The results of Sonmezdag et al. [4] suggest that the most aroma-active compounds in Iranian and Turkish basil were linalool and estragole, which were present in significant quantities in our study. The compounds present in smaller amounts also results in a decrease in similarity to fresh basil.

After heat treatment and independently of processes conditions, the volatile compounds profile was changed. In our study, the relative percentage content of eucalyptol in the sous-vide samples was higher than in both the fresh samples and the conventionally infused. The dynamics of the changes are entirely different than in drying, where high temperature caused evaporation of eucalyptol and many other VOc [32]. Unlike in this study, other authors [33] reported that the relative percentages of linalool and eucalyptol increased with increasing heating time and temperature, but they used oils with dried basil.

The most abundant compound in this study was eucalyptol, of which the highest share was noted in $\mathrm{SV}_{65}$ and the lowest in traditional infusions. In the study by Rocha et al. [7] on aromatic compounds of lemon verbena, concentrations of eucalyptol and limonene decreased with temperature at the longer steeping times. In this study, heat treatment lowered the share of volatiles giving forest and wood notes in the profile, which is in accordance with the results of Wang et al. [34], who found that high temperature can decrease the floral, woody, fatty, and sweet notes, and enhance the odor of green, roast, and fruity scents. In this study, basil infusions had a greater share of volatiles responsible for sweet, floral, and spicy notes, e.g., $\beta$-linalool and eugenol. Although no dramatic changes 
caused by cooking the basil leaves were reported by Pojjanapimol et al. [35], they reported slightly elevated levels of eugenol, similarly as in that study.

Table 4 shows volatile compounds identified in basil infusions along with references confirming the high probability of their identification in basil. The compilation considers the results of research by various authors [33,36-39], in which the chromatographic analysis was carried out using a capillary consisting of a non-polar phase with $5 \%$ participation of phenyl groups. The largest number of confirmations in the literature concerns compounds occurring in herbs in significant amounts. Due to the fact that most of the chromatographic analyses were carried out on herbal extracts or extracts, the works of other authors did not identify aliphatic alcohols and aldehydes typical for freshly cut herbs (e.g., 3-hexen-1-ol, (E) -2 -hexenal). In the sous-vide samples, there was a higher relative content of alkanes.

Table 4. List of volatile compounds identified in basil infusions by other authors.

\begin{tabular}{|c|c|c|c|}
\hline Volatile Compound * & Authors & Volatile Compound * & Authors \\
\hline Dimethyl sulfide & - & p-Mentha-1,3,8-triene & - \\
\hline Hexan & - & Octanoic acid, methyl ester & - \\
\hline 3-hexenal & - & Allo-Ocimene & - \\
\hline (E)-2-Hexenal & 2 & Cosmen & - \\
\hline 3-Hexen-1-ol & 2 & Camphor & $1,2,3,4,5$ \\
\hline (E)-2-hexen-1-ol & & Borneol & $1,2,4,5$ \\
\hline 1-Hexanol & - & Terpene-4-ol & 1,5 \\
\hline$\alpha$-Thujene & 1,5 & Dodekan & - \\
\hline Tricyclene & - & $\alpha$-Terpineol & $1,2,3,4,5$ \\
\hline$\alpha$-Pinene & $1,2,4,5$ & Estragole & $1,2,3,4$ \\
\hline Camphene & 1,2 & Bornyl acetate & $1,2,3,4,5$ \\
\hline Sabinene & $1,2,3$ & Tridecane & - \\
\hline$\beta$-pinene & $1,2,4,5$ & $\alpha$-Cubebene & - \\
\hline 1-Octen-3-ol & 3,4 & Eugenol & $1,2,4$ \\
\hline$\beta$-Mircene & $1,2,5$ & Copaene & 1,2 \\
\hline 3-Octanone & - & Methyl cinnamate & $1,2,3,5$ \\
\hline$\alpha$-Phellandrene & 2 & $\beta$-Elemene & $1,2,3,5$ \\
\hline Octanal & - & $\beta$-Caryophyllene & $1,2,3,4,5$ \\
\hline Decane & - & $\alpha$-Bergamotene & $1,2,3,4,5$ \\
\hline$\alpha$-Terpinene & 1 & $\alpha$-Guaiene & $1,2,5$ \\
\hline$\delta 3$-carene & - & $\alpha$-Humulene & $1,2,3,4$ \\
\hline o-Cymene & 2 & $\beta$-Farnesene & $1,2,3,4$ \\
\hline p-Cymene & - & epi-bicyclosesquiphellandrene & - \\
\hline Limonene & $1,4,5$ & Epizonarene & - \\
\hline Eucalyptol & $1,3,4,5$ & $\gamma$-Muurolene & - \\
\hline cis-Ocimene & $2,3,4$ & Germacrene D & $1,2,3,4,5$ \\
\hline trans-Ocimene & 1 & $\beta$-Selinene & - \\
\hline$\gamma$-Terpinene & 1,3 & $\beta$-Guaiene & 1 \\
\hline Sabinene hydrate trans & 1,4 & Isoeugenol methyl ether & - \\
\hline 1-Octanol & 2 & $\delta$-Cadinene & - \\
\hline Terpinolene & 2,4 & Bicyclogermacrene & 2 \\
\hline Undecene & - & Cubenene & - \\
\hline$\beta$-Linalool & $1,2,3,5$ & $\delta$-Guaiene & - \\
\hline Nonanal & - & $\delta$-Cadinene & $1,4,5$ \\
\hline
\end{tabular}

* volatile compounds identified in our study; 1-Beatovic et al. [37]; 2-Tarchoune et al. [36]; 3-Avetisyan et al. [38]; 4-Jordán et al. [39]; 5-Adams et al. [33].

Applied heat treatment, especially vacuum cooking, resulted in the degradation of volatile compounds associated with freshly cut grass or leaf notes. This is consistent with the results of Łyczko et al. [40], who found that even slight drying of fresh cilantro at $50{ }^{\circ} \mathrm{C}$ significantly decreases (Z)-Hex-3-en-1-ol and (E)-Hex-2-en-1-ol, and the effect is more notable with higher thermal treatment. The disappearance of almost all the compounds of the "green" note was not only observed during the drying process but also for blanching of the basil [41]. 


\subsection{Effect of Various Heat Treatment Methods on the Sensory Profile of Basil Infusions}

Herbs play an important role as a flavoring agent in food technology. The assessment of the influence of the sous-vide method on the sensory profile of herbs was not easy and required the use of a neutral food matrix (water), which would absorb flavor compounds. The use of foods as carriers, due to their complexity (protein, fats, carbohydrates, water, etc.) and interaction between food ingredients, could make the interpretation of the results even more difficult. For these reasons, it was decided to evaluate the influence of temperature on the composition of volatile compounds and to relate the results to flavor profiles using an aqueous matrix.

The phase (water or steam state) in which aroma compounds are located contributes to a better perception of odor. Heating a substance in the mouth changes its state from water to steam and improves the perception of smell [42]. The flavor sensations emerge as a complex process, the first stimulus substances are already released in the mouth, then by retronasal olfaction, aromas are transported from the oral cavity to the nasal cavity, where they connect with the olfactory receptors. During the consumption of products, many physicochemical changes take place in the oral cavity, and volatile compounds are also released. This process is influenced by the components of saliva, e.g., proteins, teeth, and tongue $[43,44]$.

This study did not demonstrate a significant effect of sous-vide cooking temperature on the odor and flavor profile evaluated by panelists. The reason for this is a long infusion time that leads to blurring the differences in intensities or not sufficiently differing parameters of the process. Although significant differences were detected using chromatographic methods, trained and experienced experts could not perceive them.

No significant differences in hedonic assessment of kenaf leave tea with different temperatures and infusion times were reported by Chong and Nyam [45]. On the other hand, a significant effect of temperature on the odor and flavor of herbs was shown in the research by Abo et al. [46]. These authors showed that oils macerated with basil or oregano at $60^{\circ} \mathrm{C}$ were characterized by a higher liked odor (in the case of oregano, also flavor) than those prepared at $20^{\circ} \mathrm{C}$. However, the opposite tendency was observed in the case of the desirable taste of rosemary oil. Moreover, it was found that herbal oils with a more intense aroma (rosemary) were rated higher in terms of overall appearance, color, taste, and smell.

More pronounced changes in flavor and odor intensity are visible during the drying process. Basil leaves that were oven-dried at a mild temperature of $60{ }^{\circ} \mathrm{C}$ reached the highest score for aroma, due to the least degradation of the aroma-flavor compounds [47]; however, the authors carried out the process without the use of water, and the research conditions were different than in this study.

Higher temperatures of other types of basil heat treatments, such as drying, affect the sensory quality of basil. It usually elicits a decrease in fresh, floral, and herbaceous odor intensity, while increasing spicy, hay-like, sweet, earthy, and woody intensity [48]. The applied temperature influences the efficiency of extraction by modulating the physicochemical properties of water. Higher temperature tends to lower the polarity of the water, increasing the solubility of the less polar compounds in the water [49].

In our research, although not significant, the intensity of the astringent sensation was slightly more notable in basil infusions prepared at a higher temperature, while it was fresh odor and flavor as well as basil flavor in infusions seeped at a lower temperature. This is in accordance with the findings of Lee and Chambers [50], who found that bitterness and astringency become stronger while green-related attributes become weaker as the brewing time and water temperature of green tea increases. This is also confirmed by the results of Miller et al. [51], who found that heat treatment of $2 \mathrm{~h}$ at 80 and $90{ }^{\circ} \mathrm{C}$ reduced the green/grass flavors' intensity to negligible levels.

Bitterness may be related to the presence of flavonoids and isoflavonoids in food. Dent et al. [52], who investigated the effect of solvents, temperature, and time on the content of phenolic compounds in sage, found that water extraction at $90^{\circ} \mathrm{C}$ was associated with a higher content of polyphenolic compounds than extraction at $60^{\circ} \mathrm{C}$. Moreover, the 
content of the aforementioned compounds increased with the increase in the processing time (from 30 to $90 \mathrm{~min}$ ). Therefore, it seems that the time of the treatment is as important as the temperature. The extended cooking time in the water medium had a positive effect on the content of flavanone glycosides and phenolic acids.

In this research, bitter taste intensity slightly but insignificantly increased with increasing heating temperature; the heating time was $1 \mathrm{~h}$, which also imitates the sous-vide heating process. Rocha et al. [7] obtained different results. The optimal combination of steeping for $6 \mathrm{~min}$ at a temperature of $96^{\circ} \mathrm{C}$, when preparing lemon verbena infusions, helps maximize of overall liking, high yield, high content of some aromatic, antioxidant, and phenolic compounds, while maintaining at a low level the extraction of the more astringent and bitter compounds, such as chlorogenic acid and epigallocatechin gallate [7].

There are no original studies in the literature on the influence of the maceration temperature of fresh herbs on the profile of volatile compounds. The authors indicate a significant influence of phenolic compounds on the aroma of herbal tinctures and beer $[53,54]$, and herbal infusions (chamomile, St. John's wort) depending on temperature (cold, or boiling water) and brewing time [55].

\subsection{Effect of Various Heat Treatment Methods on the Color of Basil Leaf Infusions}

The color of the basil varies depending on the part it comes from: leaf, stem, flower, or spike [56]. This study used only basil leaves.

The color of basil infusions measured shortly after their preparation became darker, redder, and yellower along with increasing steeping time. This is in accordance with the results of Marete et al. [57], who found that samples of feverfew (Tanacetum parthenium) aqueous infusions prepared at a temperature of $20-70{ }^{\circ} \mathrm{C}$ were darker and had a higher hue angle than those prepared at higher temperatures $\left(80-100{ }^{\circ} \mathrm{C}\right)$. As they concluded, this was not related to the content of bioactive compounds because significant increases in the total phenols content were seen at temperatures above $75^{\circ} \mathrm{C}$. Similarly, in a study by Jakubczyk et al. [58], most of the antioxidant substances in Matcha green tea were observed in infusions prepared at a higher temperature of $90^{\circ} \mathrm{C}$.

In this study, basil infusions after $2 \mathrm{~h}$ of storage under atmospheric conditions became darker, redder, and usually yellower, unlike infusions made at $85^{\circ} \mathrm{C}$. All the abovementioned results suggest that the darker color of samples processed at lower temperatures results from the oxidation of polyphenolic compounds under the influence of polyphenyl oxidase (PPO) to o-quinones [59]. These react with other quinones, phenolic compounds, proteins, and amino acids to form brown complexes. PPO activity decreased with increasing temperature and showed very low activity at $75{ }^{\circ} \mathrm{C}[59,60]$.

The sous-vide method ( $p \leq 0.05)$ resulted in darker, less green, and less yellow basil leaves than fresh and traditional steeping. The total color difference $(\Delta \mathrm{E})$ of sous-vide treated leaves was higher than for conventional treatments. The discussion on green vegetable color is a complex issue as many parameters and culinary procedures are applied by researchers. The less green color of sous-vide processed plants in comparison to traditionally treated plants was also reported by Martínez-Hernández et al. [61] in their study on broccoli, and in Rinaldi et al. [62] who studied Brussels sprouts. Moreover, in the case of sous-vide green vegetables, reduction in cooking temperature from $100{ }^{\circ} \mathrm{C}$ to $90{ }^{\circ} \mathrm{C}$ resulted in a decreased value of the parameter $a^{*}[63]$.

Cooking and storage also reduced the degree of green kale, which decreased with increasing cooking time [64]. This may be related to the degradation of chlorophyll during storage and the leaching of the color substances into the water during cooking. The study also found a lower color intensity of cooked kale than raw kale. Pero et al. [65] showed that the $\mathrm{a}^{*} / \mathrm{b}^{*}$ ratio, which is a validated indicator of the green color intensity in broccoli, increased in the initial phase of the process with the set temperature, probably because of the higher rate of water evaporation from the raw material. Further treatment leads to the loss of chlorophyll and its transformation into derivative compounds depending on 
temperature and $\mathrm{pH}$. Armesto et al. [64] also found a high correlation between greenness ( $a^{*}$ value) and total chlorophyll content.

Vacuum conditions, no-water environment, and mild temperature of the sous-vide samples $\left(60^{\circ} \mathrm{C}\right)$ favored a lower transformation of chlorophyll (green color) to pheophytin (olive green color), through the magnesium substitution of the chlorophyll by hydrogen [66]. The highest amounts of pheophytin were found in samples cooked in boiling water $\left(100{ }^{\circ} \mathrm{C}\right)$, cooked in water at a temperature of $85-90^{\circ} \mathrm{C}$, and in sous-vide samples [63].

Different conclusions were reached by Lafarga et al. [67,68], who reported no differences between the color of sous-vide and steamed broccoli, as well as Iborra-Bernad et al. [69,70], who did not observe any color difference between boiled, cook-vide, and sous-vide green beans pods.

\section{Materials and Methods}

\subsection{Study Design}

The study had a three-stage design (Figure 2). The first stage was an assessment of the effect of various temperatures for the sous-vide method on odor and flavor profile of basil aqueous infusions $(n=20)$. In the second stage, the color of basil leaves and infusion $(n=9)$ were evaluated. The third part of study was an analysis of the volatile compounds profile of basil infusions $(n=3)$, (Figure 2 ).

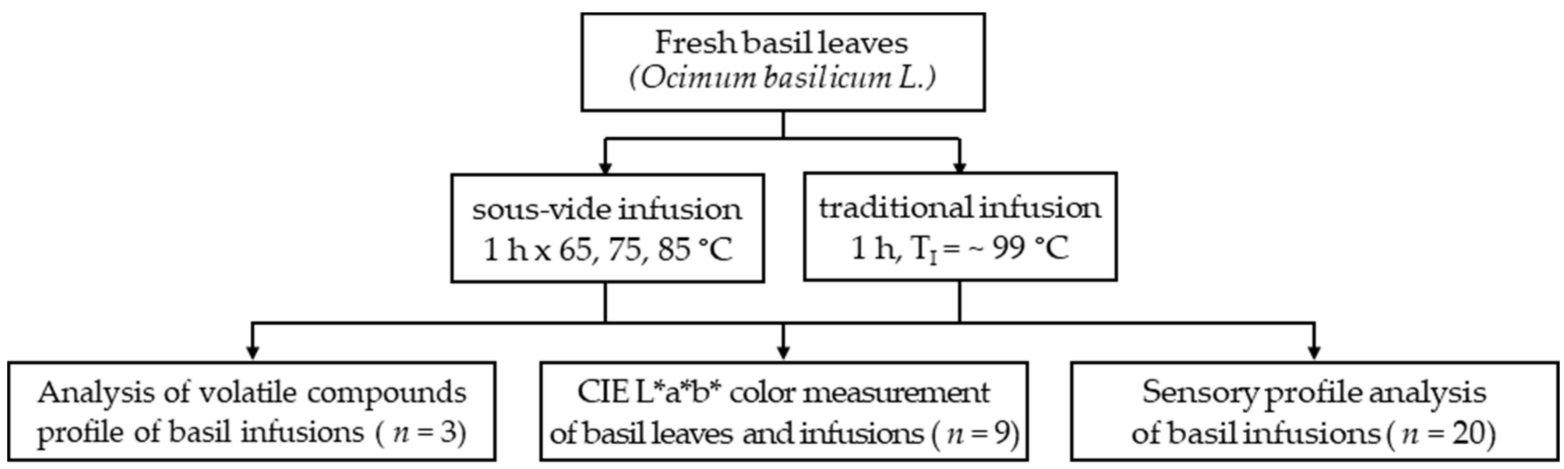

Figure 2. Study design ( $\mathrm{T}_{\mathrm{I}}$-initial temperature).

\subsection{Material}

The material was fresh basil (Ocimum basilicum L.), derived from commercial hydroponic cultivation (Baziółka, Swedeponic Polska Sp.z o.o., Kraśnicza Wola, Poland). The basil was kept in storage $\left(10-15^{\circ} \mathrm{C}\right)$ and used within 3 days. Plants cut off at $1.5 \mathrm{~cm}$ from the ground were rinsed, drained, and then the leaves were collected for further research.

Infusion preparation-As fresh herbs are usually a flavor source for plant- and animalorigin products, various cooking temperatures $\left(65,75\right.$, and $\left.85^{\circ} \mathrm{C}\right)$ and a constant time $(1 \mathrm{~h})$ for the sous-vide method were used to determine the effect of temperature on the profile of the main flavor notes. Temperatures of $65-75{ }^{\circ} \mathrm{C}$ correspond to the temperature range used in sous-vide cooking of meat and fish, while $85^{\circ} \mathrm{C}$ is used for most sous-vide processed vegetables. As a reference point, a traditional infusion was also prepared.

Traditional infusion-Fresh basil ( $20 \mathrm{~g})$ was placed in a glass beaker (400 mL capacity), then $180 \mathrm{~mL}$ of demineralized water (HLP 2O, Hydrolab Polska, Wiślina, Poland) heated to $95^{\circ} \mathrm{C}$ was poured in, covered with aluminum foil, and left at room temperature for $60 \mathrm{~min}$. After this time, the samples were cooled for $5 \mathrm{~min}$ in an ice bath to $21 \pm 1^{\circ} \mathrm{C}$. Then, the infusion was drained and subjected to further stages of research.

Sous-vide infusions-Fresh herb (20 g) was placed in a thermostable polyethylenepolyamide pouch $(130 \times 230 \mathrm{~mm})$, poured with a carrier $(180 \mathrm{~mL})$ at room temperature, vacuum packed in a vacuum packaging machine (No 691310, Stalgast, Warsaw, Poland), and placed in a sous-vide water bath (No 225448, Hendi, Gadki, Poland) preheated either 
to 65,75 , or $85^{\circ} \mathrm{C}$. After $60 \mathrm{~min}$, the vacuum bags were placed in an ice bath, cooled to $21 \pm 1^{\circ} \mathrm{C}$, strained, and subjected to the next stages of research.

\subsection{Methods}

\subsubsection{Analysis of Volatile Compounds}

To determine the profile of volatile compounds released from basil water infusions, a headspace solid-phase microextraction (HS-SPME) method coupled to gas chromatography/mass spectrometry were used. Samples of fresh basil and traditional infusions were placed respectively in glass vials $(20 \mathrm{~mL})$ and glass containers $(200 \mathrm{~mL})$ with screw caps. Samples of sous-vide basil infusions were placed in dedicated bags for sous vide vacuum packaging. All samples before SPME extraction were conditioned for $20 \mathrm{~min}$ at $35^{\circ} \mathrm{C}$ using a magnetic stirrer with heating function. A preconditioned $\left(270{ }^{\circ} \mathrm{C}, 60 \mathrm{~min}\right)$, three-phase DVB/CAR/PDMS fiber (Supelco ${ }^{\mathrm{TM}}$ Analytical, Merck Life Science Sp. z.o.o., Poznan, Poland) was placed into headspace of given sample for $10 \mathrm{~min}$ at $35^{\circ} \mathrm{C}$, and after this period the fiber was transferred to gas chromatograph injection port set to $250{ }^{\circ} \mathrm{C}$ and working in split mode (1:20) for period of $2 \mathrm{~min}$.

Chromatographic analysis and identification of volatile compounds was carried out using an Agilent 7890A (Agilent Technologies, Inc., Santa Clara, CA, USA) gas chromatograph coupled to a mass spectrometer (Inert XLMSD with Triple-Axis Detector, Agilent Technologies, Inc., Santa Clara, CA, USA) and equipped with an HP-5MS capillary column $(30 \mathrm{~m} \times 0.25 \mathrm{~mm} \times 0.25 \mu \mathrm{m}$; Agilent Technologies Inc., Santa Clara, CA, USA). GC analysis parameters was as follows: the initial temperature of the column was set to $45^{\circ} \mathrm{C}$ for period of $3 \mathrm{~min}$, then it was raised to $200^{\circ} \mathrm{C}$ at a rate of $5^{\circ} \mathrm{C} / \mathrm{min}$, and maintained for $1 \mathrm{~min}$. After this, temperature was increased to $240^{\circ} \mathrm{C}$ at a rate of $15^{\circ} \mathrm{C} / \mathrm{min}$ and final temperature was maintained for $10 \mathrm{~min}$. Helium was used as a carrier gas at a flow rate of $1 \mathrm{~mL} / \mathrm{min}$.

Mass spectra were obtained using electron ionization mode of $70 \mathrm{eV}$, the ion source temperature was set to $230^{\circ} \mathrm{C}$. The volatile compounds were identified by matching their mass spectra with database records of NIST and Wiley 8th spectra libraries (minimum $90 \%$ accuracy), and then confirmed by linear retention indices (LRI) calculated using a mixture of n-alkanes C7: C30 standards (Supelco ${ }^{\mathrm{TM}}$ Analytical, Merck Life Science Sp. z.o.o., Poznań, Poland). The quantities were expressed as percentages of the total identified signal.

\subsubsection{Sensory Analysis}

Sensory Profiling

In order to determine the intensity of dominant odor and flavor attributes and to differentiate the color of samples, sensory profiling in accordance with the ISO 13299:2016 [71] procedure was performed. Fifteen sensory descriptors were selected and defined, and then assessed by panelists on a $10 \mathrm{~cm}$ unstructured graphic scale with word anchors at extreme values ranging from none to very intensive on the right. Selection of quality descriptors for quantitative descriptive analysis was carried out in accordance with the same procedure [71]. At first, panelists tasted samples and individually proposed the list of the sensory attributes for all sensory traits of each sample. Then during the panel members' discussion led by a leader, the final list for assessment was selected. Finally, the sensory lexicon with word anchors was elaborated and agreed (Supplementary Data, Table S1). There were: fresh, basil, herbal, sweet, pungent, clove, and anise odor; color intensity; basil, fresh, and herbal flavor; sweet, and bitter taste; astringent sensation; and aftertaste. As the consistency of the infusions did not differ, its characterization was deliberately abandoned.

Sample Preparation and Presentation

Samples of basil infusions $(15 \mathrm{~mL})$ were served at room temperature $\left(21 \pm 1^{\circ} \mathrm{C}\right)$ in transparent plastic containers $(30 \mathrm{~mL})$ with a lid, then coded with a 3-digit number and served to experts in random order. Natural water and wheat bread was provided as a taste neutralizer between samples. 
Subjects and Testing Conditions

The evaluation was carried out on a group of 10 expert panelists, qualified [72] and experienced in sensory analysis, in two separate sessions with sufficient relaxation time in between. The trained panel consisted of 2 males and 8 females aged 30-55 years old.

The analysis was performed in an accredited sensory laboratory (contract No AB 564) fulfilling the requirements of the ISO standard [73] and equipped with individual test booths and sensory software ANALSENS.

\subsubsection{Instrumental Color Evaluation}

Instrumental color measurements using spectrophotometer (CM-2300d, Konica-Minolta $\mathrm{GmbH}$, Langenhagen, Germany) were carried out both basil leaves and its infusions. The equipment was set up with $\mathrm{D}_{65}$ standard illuminate $\left(10^{\circ}\right.$ observer angle $)$ and calibrated using a standard white plate (Minolta Technical Note 1994). In the case of leaves, the measurements were performed in nine replicates both before and after each heat treatment. Color of the infusions was measured using a $50 \times 38 \mathrm{~mm}$ CM-APP plastic cuvette with an optical path length of $20 \mathrm{~mm}$. Results were expressed as L* (lightness), a*(redness/greenness), and $\mathrm{b}^{*}$ (yellowness/blueness) in the CIE Lab system.

Differences $(\Delta)$ between given coordinates of leaves were calculated by subtracting the colorimetric values of heat-treated sample from the raw material values. The value of color saturation delta chroma $(\Delta C)$ was calculated using $(\Delta C)=\sqrt{ }\left(\left(\Delta \mathrm{a}^{*}\right)^{2}+\left(\Delta \mathrm{b}^{*}\right)^{2}\right)$ equation, the chroma with (Intensity of color): $C^{*}=\sqrt{ }\left[\left(a^{*}\right)^{2}+\left(b^{*}\right)^{2}\right]$ equation, while the value of total color difference $(\Delta \mathrm{E})$ with $\Delta \mathrm{E}^{*}{ }_{\mathrm{ab}}=\sqrt{ }\left[\left(\Delta \mathrm{L}^{*}\right)^{2}+\left(\Delta \mathrm{a}^{*}\right)^{2}+\left(\Delta \mathrm{b}^{*}\right)^{2}\right]$ equation.

\subsubsection{Statistical Analysis}

One-way analysis of variance (ANOVA) with Fisher's Least Significant Difference (LSD) post hoc test was applied to evaluate the significance of differences in volatile compounds composition, sensory profile, and color. Pearson correlation coefficients were calculated to relate the results of sensory profiling with the volatile compounds composition.

The statistical analysis was performed using the STATISTICA software version 13.3 PL package (StatSoft, Kraków, Poland) and considered as significant at the level of the materiality of 0.05 . Interpretation of the sensory results obtained was carried out using the Principal Component Analysis (PCA) in accordance with [74].

\section{Conclusions}

The profile of volatile compounds of basil aqueous infusions differed significantly depending on the applied steeping methods. The hypothesis that the volatile compound profile of herbs processed with the sous-vide method is superior to conventionally infused profiles has not been confirmed. Our findings show that conventionally steeped infusions were more similar to the sous-vide infusion cooked at the lowest temperature $\mathrm{SV}_{65}$, while $\mathrm{SV}_{75}$ was more similar to $\mathrm{SV}_{85}$. Long cooking at higher temperatures results in a pronounced change in aroma composition. This study did not demonstrate a significant effect of the sous-vide cooking temperature on the odor and flavor profile evaluated by the panelists. The overall sensory impression of herbs is probably more favorable when assessed on common food matrices (e.g., meat, and vegetables). Due to varied odor activity values of volatiles and non-significant differences in sensory analysis, as well as limited data on the effect of the sous-vide method on the quality of herbs and complex process of creating flavor compounds, it cannot be concluded that the sous-vide method contributes better taste and aroma of herbs than conventional cooking methods Therefore, further research involving various factors (time-temperature combination, herb concentration, food matrices used) and other methods of analysis (e.g., Gas-Chromatography-Olfactometry, e-tongue, and e-nose) is needed.

Supplementary Materials: The following are available online. Table S1: Sensory lexicon used in the study. 
Author Contributions: Conceptualization, A.G. and E.C.-S.; methodology, A.G. and K.T.; validation, A.G.; formal analysis, A.G. and K.T.; data curation, A.G.; writing-original draft preparation, A.G., E.C.-S. and E.J.; writing—review and editing, A.G., E.C.-S. and E.J.; visualization, A.G.; supervision, E.C.-S. All authors have read and agreed to the published version of the manuscript.

Funding: Research financed by Polish Ministry of Science and Higher Education within funds of Institute of Human Nutrition Sciences, Warsaw University of Life Sciences (WULS-SGGW) for scientific research.

Institutional Review Board Statement: Ethical review and approval were not obtained for this study, due to Polish regulations did not require the consent of an ethics committee for this type of study.

Informed Consent Statement: Informed consent was obtained from all subjects involved in the study. Data Availability Statement: Not applicable.

Acknowledgments: We would like to thank Maria Buła, and Grażyna Wasiak-Zys, for help in the analyses as well as the Baziółka, Swedeponic Polska Sp.z o.o.--herb producer for providing material for research.

Conflicts of Interest: The authors declare no conflict of interest. The funders had no role in the design of the study; in the collection, analyses, or interpretation of data; in the writing of the manuscript, or in the decision to publish the results.

Sample Availability: Samples are not available from the authors.

\section{References}

1. Chohan, M.; Forster-Wilkins, G.; Opara, E.I. Determination of the antioxidant capacity of culinary herbs subjected to various cooking and storage processes using the ABTS* + radical cation assay. Plant Foods Hum. Nutr. 2008, 63, 47-52. [CrossRef] [PubMed]

2. Pereira, C.; Barros, L.; Ferreira, L.C.F.G.R.A. Comparison of the Nutritional Contribution of Thirty-nine Aromatic Plants used as Condiments and/or Herbal Infusions. Plant Foods Hum. Nutr. 2015, 70, 176-183. [CrossRef] [PubMed]

3. Kowalski, R.; Kowalska, G.; Pankiewicz, U.; Mazurek, A.; Sujka, M.; Włodarczyk-Stasiak, M.; Kałwa, K. Effect of the method of rapeseed oil aromatision with rosemary Rosmarinus officinalis L. on the content of volatile fraction. LWT Food Sci. Technol. 2019, 95, 40-46. [CrossRef]

4. Sonmezdag, A.S.; Kelebek, H.; Selli, S. Characterization of bioactive and volatile profiles of thyme (Thymus vulgaris L.) teas as affected by infusion times. J. Food Meas. Charact. 2018, 12, 2570-2580. [CrossRef]

5. Assami, K.; Chemat, S.; Meklati, B.Y.; Chemat, F. Ultrasound-Assisted Aromatisation with Condiments as an Enabling Technique for Olive Oil Flavouring and Shelf Life Enhancement. Food Anal. Methods 2016, 9, 982-990. [CrossRef]

6. Hajdari, A.; Mustafa, B.; Hyseni, L.; Bajrami, A.; Mustafa, G.; Quave, C.L.; Nebija, D. Phytochemical study of eight medicinal plants of the lamiaceae family traditionally used as tea in the Sharri Mountains region of the Balkans. Sci. World J. 2020, 2020, 4182064. [CrossRef]

7. Rocha, C.; Coelho, M.; Lima, R.C.; Campos, F.M.; Pintado, M.; Cunha, L.M. Increasing phenolic and aromatic compounds extraction and maximizing liking of lemon verbena (Aloysia triphylla) infusions through the optimization of steeping temperature and time. Food Sci. Technol. Int. 2019, 25, 701-710. [CrossRef]

8. Li, Y.; Fabiano-Tixier, A.S.; Ginies, C.; Chemat, F. Direct green extraction of volatile aroma compounds using vegetable oils as solvents: Theoretical and experimental solubility study. LWT Food Sci. Technol. 2014, 59, 724-773. [CrossRef]

9. Rocha, C.; Moura, A.P.; Cunha, L.M. Consumers' associations with herbal infusions and home preparation practices. Food Qual. Prefer. 2020, 86, 104006. [CrossRef]

10. Brimson, J.M.; Prasanth, M.I.; Malar, D.S.; Brimson, S.; Tencomnao, T. Rhinacanthus nasutus "Tea" Infusions and the Medicinal Benefits of the Constituent Phytochemicals. Nutrients 2020, 12, 3776. [CrossRef]

11. Ciriello, M.; Pannico, A.; El-Nakhel, C.; Formisano, L.; Cristofano, F.; Duri, L.G.; Pizzolongo, F.; Romano, R.; De Pascale, S.; Colla, G.; et al. Sweet Basil Functional Quality as Shaped by Genotype and Macronutrient Concentration Reciprocal Action. Plants 2020, 9, 1786. [CrossRef]

12. Ciriello, M.; Formisano, L.; El-Nakhel, C.; Kyriacou, M.C.; Soteriou, G.A.; Pizzolongo, F.; Romano, R.; De Pascale, S.; Rouphael, Y. Genotype and Successive Harvests Interaction Affects Phenolic Acids and Aroma Profile of Genovese Basil for Pesto Sauce Production. Foods 2021, 10, 278. [CrossRef]

13. Prinsi, B.; Morgutti, S.; Negrini, N.; Faoro, F.; Espen, L. Insight into Composition of Bioactive Phenolic Compounds in Leaves and Flowers of Green and Purple Basil. Plants 2020, 9, 22. [CrossRef]

14. Amor, G.; Sabbah, M.; Caputo, L.; Idbella, M.; De Feo, V.; Porta, R.; Fechtali, T.; Mauriello, G. Basil Essential Oil: Composition, Antimicrobial Properties, and Microencapsulation to Produce Active Chitosan Films for Food Packaging. Foods 2021, 10, 121. [CrossRef] 
15. Kilic Büyükkurt, O.; Selli, S. Factors affecting on the release of aroma compounds. GIDA 2020, 45, 204-216. [CrossRef]

16. Gang, D.R.; Wang, J.; Dudareva, N.; Nam, K.H.; Simon, J.E.; Lewinsohn, E.; Pichersky, E. An investigation of the storage and biosynthesis of phenylpropenes in sweet basil. Plant Physiol. 2001, 125, 539-555. [CrossRef]

17. Dudai, N.; Nitzan, N.; Gonda, I. Ocimum basilicum L. (Basil). In Medicinal, Aromatic and Stimulant Plants; Springer: Cham, Switzerland, 2020; pp. 377-405.

18. Nguyen, Q.V.; Chuyen, H.V. Processing of Herbal Tea from Roselle (Hibiscus sabdariffa L.): Effects of Drying Temperature and Brewing Conditions on Total Soluble Solid, Phenolic Content, Antioxidant Capacity and Sensory Quality. Beverages 2020, 6, 2. [CrossRef]

19. Zavadlav, S.; Blažić, M.; Van de Velde, F.; Vignatti, C.; Fenoglio, C.; Piagentini, A.M.; Pirovani, M.E.; Perotti, C.M.; Bursać Kovačević, D.; Putnik, P. Sous-Vide as a Technique for Preparing Healthy and High-Quality Vegetable and Seafood Products. Foods 2020, 9, 1537. [CrossRef]

20. Gouveia, A.R.; Alves, M.; Silva, J.A.; Saraiva, C. The antimicrobial effect of rosemary and thyme essential oils against Listeria monocytogenes in sous vide cook-chill beef during storage. Procedia Food Sci. 2016, 7, 173-176. [CrossRef]

21. Alcusón, G.; Remón, S.; Salvador, M.L. Quality related aspects of sous-vide processing of borage (Borago officinalis L.) stems. LWT Food Sci. Technol. 2017, 85, 104-109. [CrossRef]

22. Dogruyol, H.; Mol, S.; Cosansu, S. Increased thermal sensitivity of Listeria monocytogenes in sous-vide salmon by oregano essential oil and citric acid. Food Microbiol. 2020, 90, 103496. [CrossRef]

23. Moura-Alves, M.; Gouveia, A.R.; de Almeida, J.M.; Monteiro-Silva, F.; Silva, J.A.; Saraiva, C. Behavior of Listeria monocytogenes in beef Sous vide cooking with Salvia officinalis L. essential oil, during storage at different temperatures. LWT Food Sci. Technol. 2020, 132, 109896. [CrossRef]

24. Amoroso, L.; Rizzo, V.; Mazzaglia, A.; Licciardello, F.; Restuccia, C.; Muratore, G. Sous-vide packing: Sensory characteristics of potato slices treated with rosemary essential oil. Ital. J. Food Sci. 2018, 41-45. [CrossRef]

25. Amoroso, L.; Rizzo, V.; Muratore, G. Nutritional values of potato slices added with rosemary essential oil cooked in sous vide bags. Int. J. Gastron. Food Sci. 2019, 15, 1-5. [CrossRef]

26. Szymandera-Buszka, K.; Waszkowiak, K.; Jędrusek-Golińska, A.; Hęś, M. Sensory Analysis in Assessing the Possibility of Using Ethanol Extracts of Spices to Develop New Meat Products. Foods 2020, 9, 209. [CrossRef] [PubMed]

27. Tangpao, T.; Chung, H.-H.; Sommano, S.R. Aromatic Profiles of Essential Oils from Five Commonly Used Thai Basils. Foods 2018, 7, 175. [CrossRef] [PubMed]

28. Acree, T.; Arn, H. Flavornet and Human Odor Space; Cornell University: Ithaca, NY, USA; Available online: https:/ /www.flavornet. org / (accessed on 10 September 2021).

29. Blank, I. Sensory relevance of volatile organic sulfur compounds in food. ACS Symp. Ser. 1999, 826, 25-53. [CrossRef]

30. Tirillini, B.; Maggi, F. Volatile Organic Compounds of the Glandular Trichomes of Ocimum basilicum and Artifacts during the Distillation of the Leaves. Appl. Sci. 2021, 11, 7312. [CrossRef]

31. Ravid, U.; Putievsky, E.; Katzir, I.; Lewinsohn, E. Enantiomeric composition of linalol in the essential oils of Ocimum species and in commercial basil oils. Flavour Fragr. J. 1997, 12, 293-296. [CrossRef]

32. Kerekes, B.; Antal, T.; Kovác, Z. Effect of various drying methods on the volatile oil Composition of basil leaves. Hung. Agric. Eng. 2019, 35, 39-44. [CrossRef]

33. Adams, A.; Kruma, Z.; Verhé, R.; De Kimpe, N.; Kreicbergs, V. Volatile profiles of rapeseed oil flavored with basil, oregano, and thyme as a function of flavoring conditions. J. Am. Oil Chem. Soc. 2011, 88, 201-212. [CrossRef]

34. Wang, Z.; Han, B.; Jing, W.; Yi, Z.; Zhang, Y.; Ren, D.; Yi, L. Effects of different steeping temperatures on the leaching of aroma components in black tea by SPME-GC-MS coupled with chemometric method. J. AOAC Int. 2019, 102, 1834-1844. [CrossRef]

35. Poijanapimol, S.; Chaiseri, S.; Cadwallader, K.R. Heat-induced changes in aroma components of holy basil (Ocimum sanctum L.). In Handbook of Flavor Characterization: Sensory Analysis, Chemistry, and Physiology; Diebler, K.D., Ed.; CRC Press: Boca Raton, FL, USA, 2004; pp. 217-230.

36. Tarchoune, I.; Baâtour, O.; Harrathi, J.; Cioni, P.L.; Lachaâl, M.; Flamini, G.; Ouerghi, Z. Essential oil and volatile emissions of basil (Ocimum basilicum) leaves exposed to $\mathrm{NaCl}$ or Na2SO4 salinity. J. Plant Nutr. Soil Sci. 2013, 176, 748-755. [CrossRef]

37. Beatović, D.; Krstic-Milošević, D.; Trifunović, S.; Šiljegović, J.; Glamočlija, J.; Ristić, M.; Jelačić, S. Chemical composition, antioxidant and antimicrobial activities of the essential oils of twelve Ocimum basilicum L. cultivars grown in Serbia. Rec. Nat. Prod. 2015, 9, 62.

38. Avetisyan, A.; Markosian, A.; Petrosyan, M.; Sahakyan, N.; Babayan, A.; Aloyan, S.; Trchounian, A. Chemical composition and some biological activities of the essential oils from basil Ocimum different cultivars. BMC Complement. Altern. Med. 2017, 17, 60. [CrossRef]

39. Jordán, M.J.; Quílez, M.; Luna, M.C.; Bekhradi, F.; Sotomayor, J.A.; Sánchez-Gómez, P.; Gil, M.I. Influence of water stress and storage time on preservation of the fresh volatile profile of three basil genotypes. Food Chem. 2017, 221, 169-177. [CrossRef]

40. Łyczko, J.; Masztalerz, K.; Lipan, L.; Iwiński, H.; Lech, K.; Carbonell-Barrachina, Á.A.; Szumny, A. Coriandrum sativum L.—Effect of Multiple Drying Techniques on Volatile and Sensory Profile. Foods 2021, 10, 403. [CrossRef]

41. Cesare, L.F.D.; Nani, R.; Viscardi, D.; Fusari, E.; Vitale, R. The Influence of Blanching-Drying and Storage on the Volatile Fraction of the Basil Leaves. Ind. Aliment. 2002, 40, 1007-1013. Available online: https://agris.fao.org/agris-search/search.do?recordID= IT2002062480 (accessed on 18 October 2021). 
42. Grabowska, J. Substancje Zapachowe [w:] (Red.) E. Sikorski, Chemia Żywności-Składniki Żywności; WNT: Warszawa, Poland, 2017; p. 172.

43. Van Ruth, S.M.; Roozen, J.P. Influence of mastication and saliva on aroma release in a model mouth system. Food Chem. 2000, 71,339-345. [CrossRef]

44. Baryłko-Pikielna, N.; Kostyra, E. Współczesne trendy wyboru i akceptacji żywności (Current trends in choice and approval of food). Przemyst Spożywczy 2004, 58, 3-6.

45. Chong, Y.K.; Nyam, K.L. Effect of brewing time and temperature on the physical properties, antioxidant activities and sensory of the kenaf leaves tea. J. Food Sci. Technol. 2021, 1-8. [CrossRef]

46. Abo, B.; Bevan, J.; Greenway, S.; Healy, B.; McCurdy, S.M.; Peutz, J.; Wittman, G. Acidification of garlic and herbs for consumer preparation of infused oils. Food Prot. Trends 2014, 34, 247-257.

47. Akah, N.P.; Eze, K.; Omah, E.C. Proximate composition, total phenol content and sensory properties of sweet basil (Ocimum basilicum L.) leaves dried using different methods. Agro-Sci. 2017, 16, 23-28. [CrossRef]

48. Calín-Sánchez, Á.; Lech, K.; Szumny, A.; Figiel, A.; Carbonell-Barrachina, Á.A. Volatile composition of sweet basil essential oil (Ocimum basilicum L.) as affected by drying method. Food Res. Int. 2012, 48, 217-225. [CrossRef]

49. Razak, N.A.; Tumin, S.M.; Tajuddin, R.; Razak, N.A.; Tumin, S.M.; Tajuddin, R. Effect of Temperature on the Color of Natural Dyes Extracted Using Pressurized Hot Water Extraction Method. Am. J. Appl. Sci. 2011, 8, 45-49. [CrossRef]

50. Lee, J.; Chambers, D.H. Sensory descriptive evaluation: Brewing methods affect flavour of green tea. Asian J. Food Agro-Ind. 2009, $2,427-439$

51. Miller, N.; Petrus, A.; Moelich, E.I.; Muller, M.; de Beer, D.; van Der Rijst, M.; Joubert, E. Heat treatment improves the sensory properties of the ultrafiltration by-product of honeybush (Cyclopia genistoides) extract. J. Sci. Food Agric. 2021. [CrossRef]

52. Dent, M.; Dragovic-Uzelac, V.; Penic, M.; Brncic, M.; Bosiljkov, T.; Levaj, B. The effect of extraction solvents, temperature and time on the composition and mass fraction of polyphenols in Dalmatian wild sage (Salvia officinalis L.) extracts. Food Technol. Biotechnol. 2013, 51, 84.

53. Rodríguez-Solana, R.; Salgado, J.M.; Domínguez, J.M.; Cortés-Diéguez, S. Phenolic compounds and aroma-impact odorants in herb liqueurs elaborated by maceration of aromatic and medicinal plants in grape marc distillates. J. Inst. Brew. 2016, 122, 653-660. [CrossRef]

54. Lentz, M. The impact of simple phenolic compounds on beer aroma and flavor. Fermentation 2018, 4, 20. [CrossRef]

55. Sentkowska, A.; Biesaga, M.; Pyrzynska, K. Effects of brewing process on phenolic compounds and antioxidant activity of herbs. Food Sci. Biotechnol. 2016, 25, 965-970. [CrossRef]

56. Simon, J.E.; Morales, M.R.; Phippen, W.B.; Vieira, R.; Hao, Z. Basil: A Source of Aroma Compounds and a Popular Culinary and Ornamental Herb. In Perspectives on New Crops and New Uses; Janick, J., Ed.; ASHS Press: Alexandria, VA, USA, 1999.

57. Marete, E.N.; Jacquier, J.C.; O'Riordan, D. Effects of extraction temperature on the phenolic and parthenolide contents, and colour of aqueous feverfew (Tanacetum parthenium) extracts. Food Chem. 2009, 117, 226-231. [CrossRef]

58. Jakubczyk, K.; Kochman, J.; Kwiatkowska, A.; Kałduńska, J.; Dec, K.; Kawczuga, D.; Janda, K. Antioxidant Properties and Nutritional Composition of Matcha Green Tea. Foods 2020, 9, 483. [CrossRef]

59. Doğan, S.; Turan, P.; Doğan, M.; Arslan, O.; Alkan, M. Purification and characterization of Ocimum basilicum L. polyphenol oxidase. J. Agric. Food Chem. 2005, 53, 10224-10230. [CrossRef]

60. Hassan, F.A.S.; Ali, E.F.; Mostafa, N.Y.; Mazrou, R. Shelf-life extension of sweet basil leaves by edible coating with thyme volatile oil encapsulated chitosan nanoparticles. Int. J. Biol. Macromol. 2021, 177, 517-525. [CrossRef]

61. Martínez-Hernández, G.B.; Artés-Hernández, F.; Gómez, P.A.; Artés, F. Quality changes after vacuum-based and conventional industrial cooking of kailan-hybrid broccoli throughout retail cold storage. LWT Food Sci. Technol. 2013, 50, 707-714. [CrossRef]

62. Rinaldi, M.; Dall'Asta, C.; Meli, F.; Morini, E.; Pellegrini, N.; Gatti, M.; Chiavaro, E. Physicochemical and microbiological quality of sous-vide-processed carrots and brussels sprouts. Food Bioprocess Technol. 2013, 6, 3076-3087. [CrossRef]

63. Guillén, S.; Mir-Bel, J.; Oria, R.; Salvador, M.L. Influence of cooking conditions on organoleptic and health-related properties of artichokes, green beans, broccoli and carrots. Food Chem. 2017, 217, 209-216. [CrossRef]

64. Armesto, J.; Gómez-Limia, L.; Carballo, J.; Martínez, S. Impact of vacuum cooking and boiling, and refrigerated storage on the quality of galega kale (Brassica oleracea var. acephala cv. Galega). LWT Food Sci. Technol. 2017, 79, 267-277. [CrossRef]

65. Pero, M.; Askari, G.; Skåra, T.; Skipnes, D.; Kiani, H. Change in the color of heat-treated, vacuum-packed broccoli stems and florets during storage: Effects of process conditions and modeling by an artificial neural network. J. Sci. Food Agric. 2018, 98, 4151-4159. [CrossRef]

66. Lau, M.H.; Tang, J.; Swanson, B.G. Kinetics of textural and color changes in green asparagus during thermal treatments. J. Food Eng. 2000, 45, 231-236. [CrossRef]

67. Lafarga, T.; Bobo, G.; Viñas, I.; Zudaire, L.; Simó, J.; Aguiló-Aguayo, I. Steaming and sous-vide: Effects on antioxidant activity, vitamin C, and total phenolic content of Brassica vegetables. Int. J. Gastron. Food Sci. 2018, 13, 134-139. [CrossRef]

68. Lafarga, T.; Viñas, I.; Bobo, G.; Simó, J.; Aguiló-Aguayo, I. Effect of steaming and sous vide processing on the total phenolic content, vitamin C and antioxidant potential of the genus Brassica. Innov. Food Sci. Emerg. Technol. 2018, 47, 412-420. [CrossRef]

69. Iborra-Bernad, C.; Philippon, D.; García-Segovia, P.; Martínez-Monzó, J. Optimizing the texture and color of sous-vide and cook-vide green bean pods. LWT Food Sci. Technol. 2013, 51, 507-513. [CrossRef] 
70. Iborra-Bernad, C.; García-Segovia, P.; Martínez-Monzó, J. Physico-chemical and structural characteristics of vegetables cooked under sous-vide, cook-vide, and conventional boiling. J. Food Sci. 2015, 80, 1725-1734. [CrossRef]

71. ISO 13299:2016. Sensory Analysis-Methodology_General Guidance for Establishing a Sensory Profile; ISO: Geneva, Switzerland, 2016.

72. Polish Standard PN-EN ISO 8586:2014-03. Sensory Analysis-General Guidelines for the Selection, Training and Monitoring of Selected Assessors and Expert Sensory Assessors; Polish Committee for Standardization: Warsaw, Poland, 2014.

73. ISO Standard ISO 8589:2007. Sensory Analysis_General Guidance for the Design of Test Rooms; ISO: Geneva, Switzerland, 2007.

74. Borgognone, M.G.; Bussi, J.; Hough, G. Principal component analysis in sensory analysis: Covariance or correlation matrix? Food Qual. Prefer. 2001, 12, 323-326. [CrossRef] 